A simple pH-based method for estimation of $\mathrm{CO}_{2}$ absorbed in alkanolamines

Asha Masohan ${ }^{1}$, Mamshad Ahmed ${ }^{1}$, Sushil Kumar Nirmal ${ }^{1}$, Ajay Kumar ${ }^{2}$ and Madhukar Onkarnath Garg ${ }^{1}$

${ }^{1}$ Indian Institute of Petroleum, Mohkampur, Dehradun, Uttarakhand, 248005, India.

${ }^{2}$ Chemical Metrology Section, National Physical Laboratory, New Delhi, 110012, India.

amasohan@iip.res.in, masohan_asha@hotmail.com

Abstract: $\mathrm{CO}_{2}$ is recognized as a major contributor of global warming. We report a facile, sensitive and accurate method for estimating $\mathrm{CO}_{2}$ content in the alkanolamine solvents. It can be applied to a host of alkanolamine solvents as well as solvent mixtures for screening for prospective absorbent for $\mathrm{CO}_{2}$ capture. In this method, $\mathrm{pH}$ of the $\mathrm{CO}_{2}$-loaded absorbent sample is measured and referred to a "reference $\mathrm{pH}$ graph" of corresponding amine with sulphuric acid that is constructed under specific conditions. The authenticity of the method was validated from known amounts of $\mathrm{CO}_{2}$ added in the form of $\mathrm{CO}_{2}$-saturated water to three different types of alkanolamines i.e. the primary (monoethanolamine, MEA), secondary (diethanolamine, DEA) and tertiary (triethanolamine, TEA) alkanolamines. The method was compared with known methods and found to be better in terms of accuracy.

Keywords: $\mathrm{CO}_{2}$ estimation, $\mathrm{pH}, \mathrm{pK}_{\mathrm{a}}$, Alkanolamines, Gas absorption.

Introduction

Carbon dioxide $\left(\mathrm{CO}_{2}\right)$ has been proven to be responsible for $80 \%$ of green house gases, contributing to the increase of earth's temperature. Half of the $\mathrm{CO}_{2}$ emission is produced by industries and power plants using fossil fuel (Desideri et al., 1999). Consequently, modern research geared towards developing new $\mathrm{CO}_{2}$ capture technologies worldwide.

Traditionally, absorption/stripping via circulated aqueous alkanolamines have been the most favored technology for removing $\mathrm{CO}_{2}$ from process and waste gas streams. The existing commercial processes based on alkanolamines are highly energy- and cost- intensive. As much as $80 \%$ of the total energy consumption in an alkanolamine absorption process occurs during solvent regeneration (White. et al., 2003). Therefore, search is on for new improved solvents with higher rates and capacities for absorption of $\mathrm{CO}_{2}$, high degradation resistance, low corrosiveness and low energy use for regeneration. Such a solvent will decrease both capital and operating costs of the process thereby reducing the cost of electricity at thermal power plant when $\mathrm{CO}_{2}$ removal is integrated in the plant. Many new solvents are being researched for potential commercial use to remove $\mathrm{CO}_{2}$ from flue gas streams.

Three classes of alkanolamines, primary (MEA), secondary (DEA) and tertiary (TEA and methyl diethanolamine, MDEA) or their mixtures, are generally used as absorbing liquids. The different categories of amines differ in the type of mechanisms with which they react with $\mathrm{CO}_{2}$ as well as the reaction products and the heats of reaction.
Typically primary and secondary amines form acidic anion species like bicarbonate, carbonate and carbamate with $\mathrm{CO}_{2}$ (equations 1 to 5 ).

$$
\begin{aligned}
& \mathrm{R}_{2} \mathrm{NH}+\mathrm{H}_{2} \mathrm{O} \leftarrow \mathrm{R}_{2} \mathrm{NH}_{2}{ }^{+}+\mathrm{OH}^{-} \\
& \mathrm{CO}_{2}+2 \mathrm{H}_{2} \mathrm{O} \longleftrightarrow \mathrm{HCO}_{3}^{-}+\mathrm{H}_{3} \mathrm{O}^{+} \\
& \mathrm{HCO}_{3}^{-}+\mathrm{H}_{2} \mathrm{O} \longleftrightarrow \mathrm{CO}_{3}^{--}+\mathrm{H}_{3} \mathrm{O}^{+} \\
& \mathrm{CO}_{2}+\mathrm{R}_{2} \mathrm{NH} \longleftrightarrow \mathrm{R}_{2} \mathrm{NH}^{+} \mathrm{COO}^{-} \text {(zwitterions) } \\
& \mathrm{R}_{2} \mathrm{NH}^{+} \mathrm{COO}^{-}+\mathrm{R}_{2} \mathrm{NH} \longleftrightarrow \\
& \mathrm{R}_{2} \mathrm{NCOO}^{-}+\mathrm{R}_{2} \mathrm{NH}_{2}{ }^{+} \\
& \text {(carbamate) (protonated amine) }
\end{aligned}
$$

Tertiary amines cannot form carbamate species, because they do not have hydrogen attached to the nitrogen atom. Typically tertiary amines react according to equation 6 .

$$
\mathrm{CO}_{2}+\mathrm{R}_{3} \mathrm{~N}+\mathrm{H}_{2} \mathrm{O} \longleftrightarrow \mathrm{HCO}_{3}^{-}+\mathrm{R}_{3} \mathrm{NH}^{+} \quad \ldots \text { (6) }
$$

One of the main criteria for selection of suitable solvent requires estimation of $\mathrm{CO}_{2}$ in both the gas and liquid phases for ascertaining the mechanism and material balance for rate and capacity estimation of the solvent. Accurate amounts of $\mathrm{CO}_{2}$ in liquid solvents are also required to remove discrepancies in parameter estimation in simulation and modeling by mathematical model for plant design and feasibility studies.

There are many methods available for estimation of carbon dioxide in absorbing liquids specifically the alkanolamines. The UOP method 826-81 (UOP Method, 1981) uses phosphoric acid to liberate the dissolved $\mathrm{CO}_{2}$ in amine solutions. The method involves quite a few steps like use of mercury for determining the volume of calibrated tube, introducing sample of $\mathrm{CO}_{2}$-containing amine, adding phosphoric acid to liberate $\mathrm{CO}_{2}$ from sample and use of mercury leveling bulb to force the liberated gas into the measuring burette repeatedly till no further $\mathrm{CO}_{2}$ remains dissolved in the amine and washing of carbonimeter. Regarding precision of the method no estimated standard deviation is reported due to lack of sufficient data to permit this calculation with at least 4 degrees of freedom. Also the elapsed time for one analysis is 1.0 hour.

Currently the most popular analytical method for determining the acid gas concentration in aqueous amine solutions employs a wet chemistry titration. In the method for $\mathrm{CO}_{2}$, the amine sample is mixed with an excess of standard base and heated to boiling. Since the amine-acid gas complex is thermally unstable, the acid gas is converted into an ionic species and is precipitated by an appropriate metal salt like $\mathrm{BaCl}_{2}$. The filtrate is titrated with a standard acid to determine the concentration of uncarbonated amine in the sample (here onwards termed as " $\mathrm{BaCl}_{2}$ method"). Indicators like bromocresol green, cresol red and phenolphthalein etc.
Research article

(CIndian Society for Education and Environment (iSee)
"pH-based $\mathrm{CO}_{2}$ estimation" http://www.indjst.org
Asha Masohan et al. Indian J.Sci.Technol. 
are commonly used to indicate the end points (Coldrey \& Harris, 1976; Ellis et al., 1963; Hikita et al., 1977; Jensen et al., 1954; Gas Conditioning Fact Book, 1962; Jou et al., 1982; Weiland \&Trass, 1969). The $\mathrm{CO}_{2}$ content of the solution is calculated as the difference between the total amine and uncarbonated amine. However, the calculations require assumption of $1: 1$ stoicheometry between amine and $\mathrm{CO}_{2}$ (Weiland et al., 1969) which is not true. Another titrimetric method for determination of $\mathrm{CO}_{2}$ in ethanolamine is the UOP method 829-82 [here onwards termed as "MeONa method"] (UOP Method, 1982). The method involves dissolution of $\mathrm{CO}_{2}$-absorbed sample in anhydrous methanol. The amine/methanol solution is titrated with standard methanolic sodium hydroxide solution using thymolphthalein as the indicator and calculating the $\mathrm{CO}_{2}$ content.

The wet chemistry methods involving precipitations and titrations have serious disadvantages. The total time required for an experienced technician to analyze one carbonated amine solution could be as long as 1-2 hours. During part of this time, the $\mathrm{CO}_{2}$ amine solution is open to the atmosphere so both flashing of $\mathrm{CO}_{2}$ and degradation of the amine can occur. Also stoicheometry for different types of alkanolamines (primary, secondary and tertiary) for $\mathrm{CO}_{2}$ is usually assumed as one which is not true and leads to erratic results for $\mathrm{CO}_{2}$ content. This has serious bearing on results for the weight of $\mathrm{CO}_{2}$ estimated because the species formed upon reaction of alkanolamine with $\mathrm{CO}_{2}$ may vary from monoionic $\mathrm{HCO}_{3}^{-}$ and carbamate to di-ionic $\mathrm{CO}_{3}{ }^{--}$ions (equations. 2, 3 and 5 ) in different proportions. Freshly prepared solutions of standardized acid and base must also be available and Research article CIndian Society for Education and Environment (iSee)
Fig. 1. $\mathrm{pH}$ graph of 2.6M AMP vs $\mathrm{H}_{2} \mathrm{SO}_{4}$

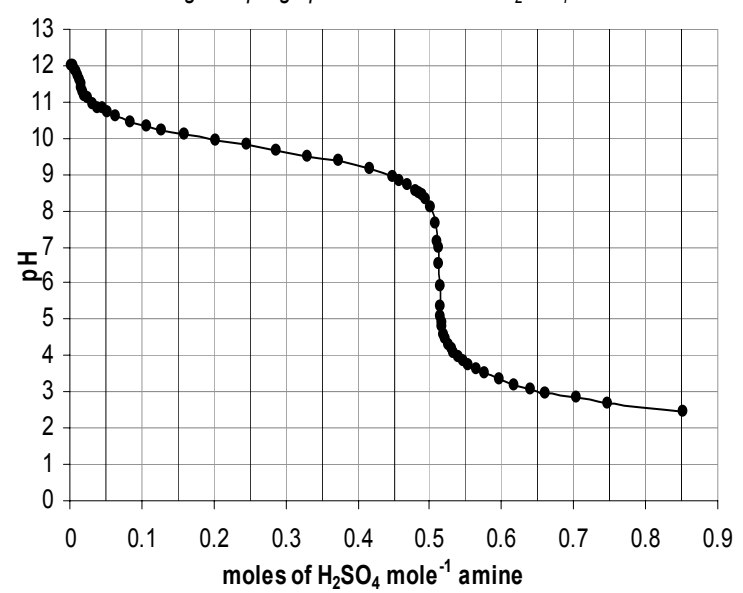

Fig. 2. $p H$ graph of MEA, DEA, TEA and MDEA

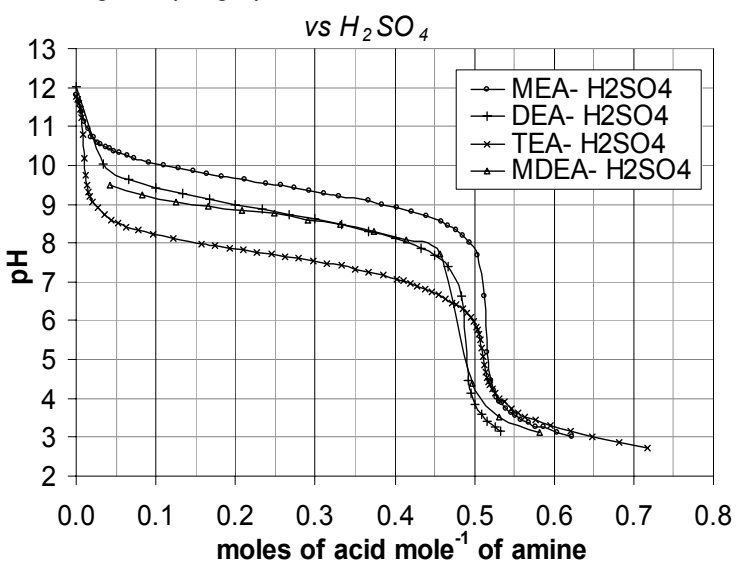

Fig. 3. $\mathrm{pH}$ graph of 2.6M AMP vs acetic acid

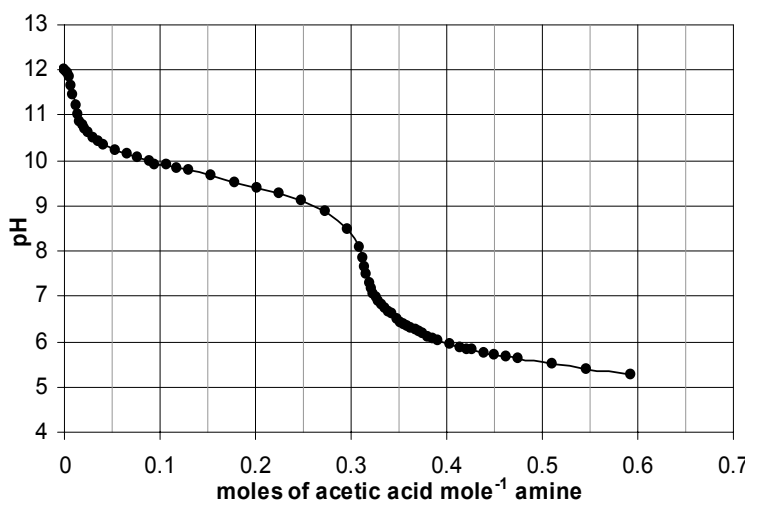

"pH-based $\mathrm{CO}_{2}$ estimation" http://www.indjst.org
Vol.2 No 4 (Apr. 2009)

ISSN: 0974- 6846 daily before use. Blank runs should also be made arnold \& Pearce, 1960). Most amine functionality and are nonspecific and inaccurate (Brydia \& Pearce, 1967).

A method based on GC has been reported by Robbins and Bullin (Robbins \& Bullin, 1984) which is fast, accurate and analyses the amine solution for acid gases like $\mathrm{H}_{2} \mathrm{~S}$ and $\mathrm{CO}_{2}$, hydrocarbons, water and amine content. However, the example cited is with MDEA only and the structural characteristics of other alkanolamines are bound to affect the retention time of the constituent components and lot of work needs to be done on their separation using the prospective solvents used in $\mathrm{CO}_{2}$ separation for this method to become a standard method. Moreover the effects of amine salts, that result when the alkanolamine reacts with $\mathrm{CO}_{2}$, on retention time is not known.

Thus, the analytical methods reported above can provide only the directional values for total amount of $\mathrm{CO}_{2}$ in the lean and rich amines but are not suited for studies involving small changes in $\mathrm{CO}_{2}$ content as is required in studies like kinetics of absorption in the stirred contactor/wetted-wall column. The number of data points in these studies is large and the $\mathrm{CO}_{2}$ build up that starts from just a few mg is very gradual. Present studies were, therefore, aimed to develop a sensitive and fast method for estimation of $\mathrm{CO}_{2}$ for analyzing sequential build up of $\mathrm{CO}_{2}$ in the alkanolamine solvents ranging from $\mathrm{ppm}$ to percent level for absorption-based studies. The method was applied to $\mathrm{CO}_{2}$-loaded alkanolamines which were obtained after absorption of $\mathrm{CO}_{2}$ in the alkanolamines of different chemical structures (MEA, DEA, TEA etc.).

Experimental

1. Reagents and equipments: All the chemicals used in the present study were $97-99 \%$ pure. $\mathrm{H}_{2} \mathrm{SO}_{4}$ (98\%), DEA (98\%), TEA (97\%) and $\mathrm{NaOH}(97 \%)$ were purchased from

Asha Masohan et al. Indian J.Sci.Technol. 
SD Fine - Chem. Ltd., India. HCl, MEA (98\%), oxalic acid ampules (volumetric solution $\mathrm{N} / 10$ ) and $\mathrm{BaCl}_{2}(99 \%)$ were purchased from Qualigens, India while MDEA (99+\%) was purchased from Aldrich Organics, New Jersy, USA. Methanol $(\geq 99 \%)$ from Merck Limited, India; Acetic acid (99.8\%) from Rankem Fine Chemicals Ltd., India and $\mathrm{Na}_{2} \mathrm{CO}_{3}$ from $\mathrm{BDH}$, E. Merck, India and 2-amino-2-methyl-1propanol (AMP) from Merck Schuchardt OHG, Germany were purchased. All solutions were prepared in double distilled water. Thymolphthalein indicator solution taken was from Loba Chemie Pvt. Ltd., India.

$\mathrm{pH}$ meter used was of Thermo Orion, Model 420, Beverly, MA 01915, USA. All titrations were carried out at $25^{\circ} \mathrm{C}$.

\section{Preparation of solutions}

$100 \mathrm{ml}$ of desired strengths (1M or $2.6 \mathrm{M})$ of MEA, DEA, TEA, MDEA, and AMP absorbents were prepared. Methanolic $\mathrm{NaOH}$ $(0.05 \mathrm{M})$ was prepared by dissolving $2.1 \mathrm{~g} \mathrm{NaOH}$ in $100 \mathrm{ml}$ water and making up the solution to $1 \mathrm{~L}$ by adding methanol as given in reference (UOP Method, 1982). $\mathrm{BaCl}_{2}$ used was $0.68 \mathrm{M}$ while $\mathrm{H}_{2} \mathrm{SO}_{4}$, acetic acid and oxalic acids used for $\mathrm{pH}$ titration were $0.1 \mathrm{~N}$.

$250 \mathrm{ml}$ each of $0.05 \mathrm{~N} \mathrm{NaOH}$, $0.06 \mathrm{M} \mathrm{BaCl}_{2}$ and $0.02 \mathrm{~N} \mathrm{HCl}$ were prepared for use for estimation of $\mathrm{CO}_{2}$ in $\mathrm{CO}_{2}$-saturated water.

\section{Titration for plotting of} reference graphs

10 Drops of thymolphthalein indicator were added to $20 \mathrm{ml}$ of methanol in a $100 \mathrm{ml}$ beaker. This solution was titrated against methanolic $\mathrm{NaOH}$ (termed as $\mathrm{MeONa}$ ) till light blue color appeared. $3 \mathrm{ml}$ of $(2.6 \mathrm{M})$ solution of AMP was added to this mixture. Moles of amine taken were calculated by dividing weight of amine in $3 \mathrm{ml}$ solution by its molecular weight. $\mathrm{pH}$ of this solution was noted. The resulting methanolic solution of amine was then titrated against $\mathrm{H}_{2} \mathrm{SO}_{4}$ with constant stirring by magnetic stirrer. Research article

CIndian Society for Education and Environment (iSee)
Fig. 4. $p H$ graph of MEA, DEA and TEA vs oxalic acids

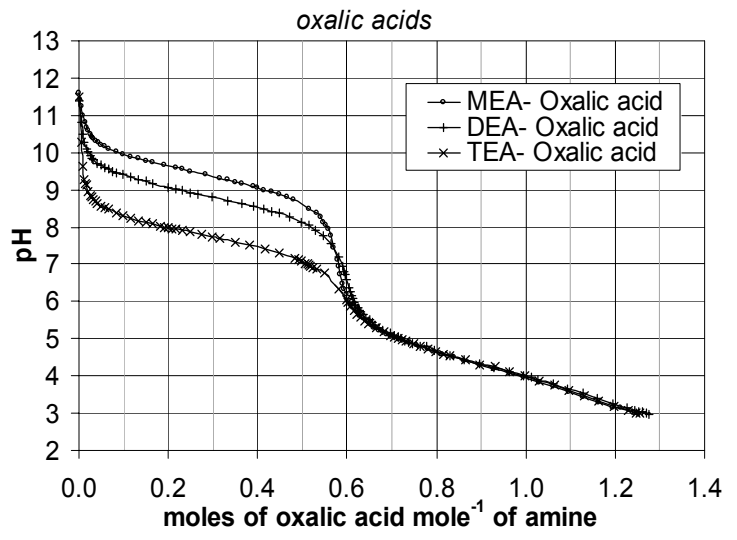

Fig. 5. Estimation of $\mathrm{CO}_{2}$ content in MEA with time

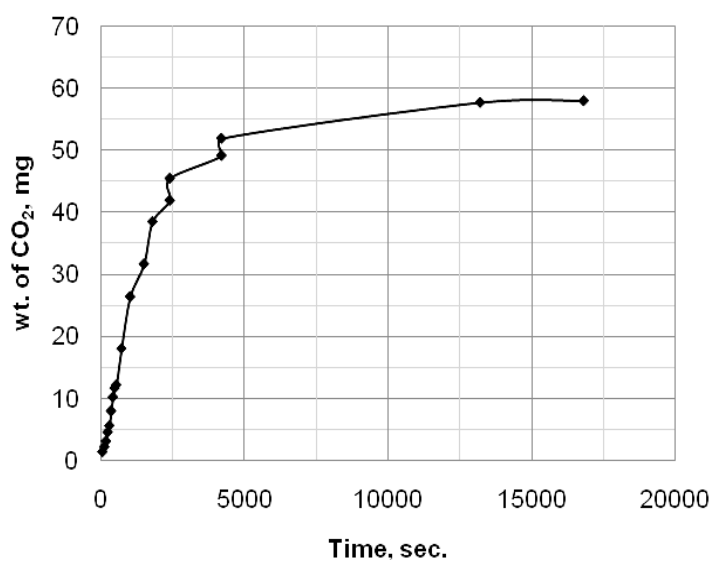

Fig. 6. Results of estimation of $\mathrm{CO}_{2}$ in alkanolamines

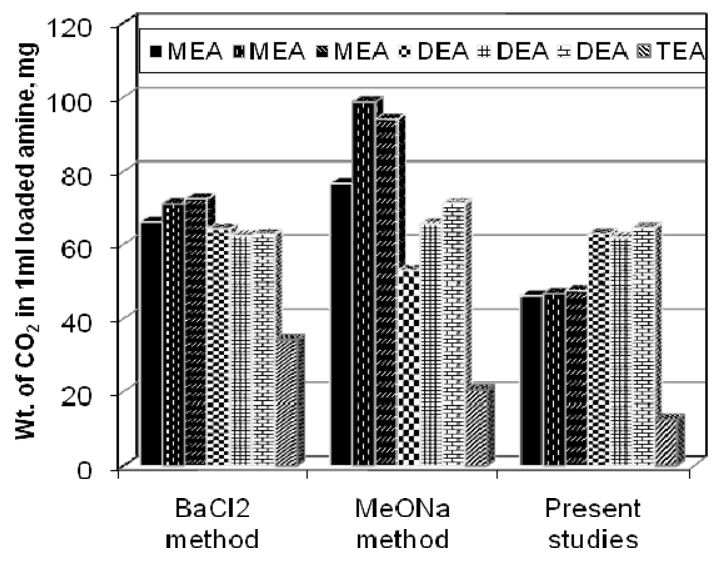

After every small from the graph.

"pH-based $\mathrm{CO}_{2}$ estimation" http://www.indjst.org
ISSN: 0974- 6846 oted. Addition of acid increased the temperature of mixture and was allowed to cool to $25^{\circ} \mathrm{C}$ before taking the $\mathrm{pH}$ reading. Initial $\mathrm{pH}$ of amine was nearly 12 . Readings were taken till the $\mathrm{pH}$ fell to nearly 3 ( $\mathrm{pH}$ range of acid). Weight of acid added was calculated from its normality and the volume added. The weight thus obtained was converted to moles of acid by dividing with 98 and subsequently to moles acid mole ${ }^{1}$ amine by dividing the moles of acid by moles of amine. A graph was plotted for moles acid mole ${ }^{-1}$ amine $v s$. corresponding $\mathrm{pH}$ for the whole $\mathrm{pH}$ range. This was the "reference pH graph" (Fig. 1).

Similarly reference $\mathrm{pH}$ graphs were obtained for MEA, DEA, TEA and MDEA with $\mathrm{H}_{2} \mathrm{SO} 4$ (Fig. 2). Graphs were also plotted for 2.6M AMP (Fig. 3) with acetic acid and MEA, DEA and TEA with oxalic acid (Fig. 4) to study the effect of structure of acid on $\mathrm{pH}$ curve and stoicheometry.

4. Preparation of $\mathrm{CO}_{2}$-loaded alkanolamine samples

4.1. Absorption of $\mathrm{CO}_{2}$ in alkanolamine: $50 \mathrm{ml}$ of $1 \mathrm{M}$ solution of MEA was taken in a $100 \mathrm{ml}$ three-neck round bottom flask. $\mathrm{CO}_{2}$ absorption in amine was started by passing $\mathrm{CO}_{2}$ gas at a flow rate of $5.5 \mathrm{sec}$ for $10 \mathrm{ml}$ of $\mathrm{CO}_{2}$ gas. Absorption was continued for $1 \mathrm{~h}$. This resulted in the $\mathrm{CO}_{2}$-loaded amine sample.

4.2. $\mathrm{pH}$ Measurement of $\mathrm{CO}_{2}$ loaded amine samples: Alkaline solution of $20 \mathrm{ml}$ methanol was prepared in the same way as under 3 by titrating with $\mathrm{MeONa}$ till blue to thymolphthalein indicator. $1 \mathrm{ml}$ of the $\mathrm{CO}_{2}$-loaded MEA sample prepared under 4.1 was immediately added to this solution. The blue solution turned colorless because of acidic $\mathrm{CO}_{2}$ in amine. $\mathrm{pH}$ of this solution was noted and referred to the corresponding $\mathrm{pH}$ value on the reference $\mathrm{pH}$ graph plotted under 3 . Corresponding moles acid mole $^{-1}$ amine was noted 
4.3. Calculations for weight of $\mathrm{CO}_{2}$ in loaded amine: The weight of $\mathrm{CO}_{2}$ is calculated from the moles acid mole ${ }^{-1}$ amine obtained from reference $\mathrm{pH}$ graph in 4.2 as given below (equations 7 to 10 ):

$$
\text { Moles } \begin{aligned}
\mathrm{CO}_{2} \text { mole }{ }^{-1} \text { amine } & =\frac{\text { Moles of } \mathrm{CO}_{2}}{\text { Moles of amine }} \\
& =\frac{\text { Weight of } \mathrm{CO}_{2} / 44}{\text { Moles of amine }}
\end{aligned}
$$

Weight of $\mathrm{CO}_{2}=$ Moles $\mathrm{CO}_{2}$ mole ${ }^{-1}$ amine $\times$ Moles of

$$
\text { amine } \times 44
$$

$=$ Moles $\mathrm{CO}_{2}$ mole $^{-1}$ amine $\times \frac{\text { Weight of amine }}{\text { Mol. Wt. of amine }} \times 44$

( ${ }^{*}$ Weight of amine is the weight in the volume taken for $\mathrm{pH}$ estimation)

\section{Validation of results}

5.1. Reparation of saturated solution of $\mathrm{CO}_{2}$ in water:

$100 \mathrm{ml}$ of distilled water was taken and degasified over ultrasonic bath for $1 \mathrm{~h} . \mathrm{CO}_{2}$ was then passed through this water (maintained at $25^{\circ} \mathrm{C}$ ) at the same flow rate as under 4.1 for $1 \mathrm{~h}$. Estimation of $\mathrm{CO}_{2}$ was done by taking 5 $\mathrm{ml}$ of this $\mathrm{CO}_{2}$-saturated water in a mixture of $10 \mathrm{ml}$ $\mathrm{NaOH}$ and $10 \mathrm{ml} \mathrm{BaCl}$ and titrating excess $\mathrm{NaOH}$ with $\mathrm{HCl}$. Amount of $\mathrm{CO}_{2}$ was calculated by the difference.

5.2. Adding known volume of $\mathrm{CO}_{2}$-saturated water to amine and estimating by the method developed: $3 \mathrm{ml}$ of alcoholic amine solution of 2.6M MEA was prepared in similar way as mentioned under 2 . A $5 \mathrm{ml}$ sample of $\mathrm{CO}_{2-}^{-}$ saturated water prepared as above was added to this amine solution. $\mathrm{pH}$ of this mixture was noted. It is to be

noted that addition of $5 \mathrm{ml}$ water (as $\mathrm{CO}_{2}$-saturated solution) results in dilution effect on concentration of amine from $3 \mathrm{ml}$ to $8 \mathrm{ml}$ i.e. by a factor of 2.66. So the strength of amine reduces to $1 \mathrm{M}$ after addition of $\mathrm{CO}_{2-}$ saturated water. Therefore, the "reference $\mathrm{pH}$ graph" to be used for reference of $\mathrm{pH}$ for this sample was that constructed with $1 \mathrm{M}$ MEA solution. From the $\mathrm{pH}$ value of the sample moles of acid mole ${ }^{-1}$ amine was noted from $\mathrm{pH}$ graph and amount of $\mathrm{CO}_{2}$ calculated by using equations 7-10. Similar estimations were also made by adding $5 \mathrm{ml}$ of the above mentioned $\mathrm{CO}_{2}$-saturated water in 2.6M solutions of DEA and TEA and referring to the "reference $\mathrm{pH}$ graphs" of $1 \mathrm{M}$ solutions of corresponding amines. The results obtained (Table 1) were compared with the amount of $\mathrm{CO}_{2}$ actually present in $5 \mathrm{ml}$ of $\mathrm{CO}_{2-}$ saturated water (estimated earlier as under 5.1).

The estimations for mixtures containing same volumes of $\mathrm{CO}_{2}$-saturated water in the three amines were also done by two of the reported, the $\mathrm{MeONa}$ and the $\mathrm{BaCl}_{2}$, methods (Table 1).

\section{Estimation of $\mathrm{CO}_{2}$ in loaded amines}

Based on the accuracy of the results, the present $\mathrm{pH}$ based method was then used in estimating $\mathrm{CO}_{2}$ content in the $\mathrm{CO}_{2}$-loaded amine samples prepared as described under 4.1 .

Completely loaded samples of alkanolamines: $3 \mathrm{ml}$ of the $\mathrm{CO}_{2}$-absorbed amine sample was added to $20 \mathrm{ml}$ of alkaline methanol as under 3 . pH of the sample is noted and moles acid mole ${ }^{-1}$ amine obtained from the MEA$\mathrm{H}_{2} \mathrm{SO}_{4}$. Weight of $\mathrm{CO}_{2}$ absorbed in amine is then calculated from the value of moles acid mole ${ }^{-1}$ amine. Results were compared with those obtained by the

\begin{tabular}{|c|c|c|c|c|c|}
\hline \multirow{4}{*}{$\begin{array}{l}\text { Amin } \\
\mathrm{e}\end{array}$} & \multirow{4}{*}{$\begin{array}{l}\text { Strength } \\
\text { of } \\
\text { amine } \\
\text { solution, } \\
\text { (M) }\end{array}$} & \multicolumn{4}{|c|}{ Wt. of $\mathrm{CO}_{2}$ in $5 \mathrm{~mL}$ of $\mathrm{CO}_{2}$-saturated water $(\mathrm{mg})$} \\
\hline & & \multicolumn{4}{|c|}{$\mathrm{CO}_{2}$ estimated } \\
\hline & & \multirow{2}{*}{$\begin{array}{l}\text { In water } \\
\text { Alkaline } \\
\mathrm{BaCl}_{2} \\
\text { Method }\end{array}$} & \multicolumn{3}{|l|}{ In amine } \\
\hline & & & $\begin{array}{l}\mathrm{BaCl}_{2} \\
\text { Method } \\
\text { (Literature) }\end{array}$ & $\begin{array}{l}\text { Methanolic } \\
\text { NaOH Method } \\
\text { (UOP method, } \\
\text { 1982) }\end{array}$ & $\begin{array}{l}\text { from } \mathrm{pH} \\
\text { reference graph } \\
\text { of amine with } \\
\mathrm{H}_{2} \mathrm{SO}_{4}\end{array}$ \\
\hline MEA & $2.67 \mathrm{M}$ & 5.701 & 5.5 & 6.1813 & 5.984 \\
\hline \multirow[t]{2}{*}{ DEA } & $2.67 \mathrm{M}$ & & - & 8.11297 & 2.816 \\
\hline & & & & & $(\times 1.9=5.35)$ \\
\hline TEA & $2.67 \mathrm{M}$ & & 11.44 & 8.11297 & 5.104 \\
\hline MEA & $2.67 \mathrm{M}$ & 5.632 & 6.41 & 4.699 & 5.55 \\
\hline \multirow[t]{2}{*}{ DEA } & $2.67 \mathrm{M}$ & & - & 8.223 & 3.168 \\
\hline & & & & & $(\times 1.9=6.02)$ \\
\hline TEA & $2.67 \mathrm{M}$ & & 7.32 & 9.3985 & 5.346 \\
\hline MEA & $2.67 \mathrm{M}$ & 5.700 & 6.64 & & 5.9 \\
\hline \multirow[t]{2}{*}{ DEA } & $2.67 \mathrm{M}$ & & 6.18 & & 2.99 \\
\hline & & & & & $(\times 1.9=5.68)$ \\
\hline TEA & $2.67 \mathrm{M}$ & & 7.78 & & 5.34 \\
\hline
\end{tabular}

Table 1. Estimation of saturated amount of $\mathrm{CO}_{2}$ in water as such and after addition in different amines

Research article

CIndian Society for Education and Environment (iSee)
"pH-based $\mathrm{CO}_{2}$ estimation" http://www.indjst.org
$\mathrm{MeONa}$ and $\mathrm{BaCl}_{2}$ methods. Similar estimations were made for $\mathrm{CO}_{2}$ absorbed in DEA and TEA. The results are shown in Table 2.

Partially loaded samples of alkanolamines containing variable amounts of $\mathrm{CO}_{2}$ : That the method is suitable for any content of $\mathrm{CO}_{2}$ in alkanolamines was tested by conducting kinetic experiments in stirred cell. $\mathrm{CO}_{2}$ was passed at the interphase of the alkanolamine with stiiring of the liquid phase and collecting $\mathrm{CO}_{2}$-absorbed samples at an interval of few seconds (30 seconds) to minutes till the end of experiment. The results are shown in Fig. 5. Similar estimations were made for $\mathrm{CO}_{2}$ in DEA and TEA also. In case of secondary amine like DEA it was observed that the results neede to be multiplied by a factor of 1.9 for exact amounts (perhaps because of stoicheometric requirements).

Asha Masohan et al. Indian J.Sci.Technol. 
Results and discussions

Because of the large number of new that are being

screened today for translating into a costeffective technology and the inherent disadvantages associated

with the wet chemistry methods as is realized by the scientific community, a new method developed in this laboratory is being reported. $A$. Structures and $p K_{a} s$ of the materials used: Structures of the alkanolamines used in present study are shown in Table 3. These structures include all the three types i.e. the primary, secondary and tertiary alkanol monoamines. The pKa values for the amine-acid systems of the present studies are provided in Table 4. The reported values are for aqueous solutions while the experimentally determined values are for the methanolic solutions of alkanolamines. The latter are being reported for the first time. As expected $\mathrm{pK}_{\mathrm{a}}$ of MEA, DEA and triethanolamine (TEA) goes on decreasing as the substitution on nitrogen atom increases. However, these values are lower than

Table 2. Estimation of $\mathrm{CO}_{2}$ in the loaded amine samples ( $m g$ )

\begin{tabular}{|l|l|l|l|}
\hline Amines & $\begin{array}{l}\mathrm{BaCl}_{2} \\
\text { method }\end{array}$ & $\begin{array}{l}\text { MeONa } \\
\text { method }\end{array}$ & $\begin{array}{l}\text { Reference } \mathrm{pH} \text { graph } \\
\text { method }\end{array}$ \\
\hline MEA & 66.17 & 76.75 & 46.28 \\
\hline MEA & 71.1 & 98.7 & 46.8 \\
\hline MEA & 72.5 & 94 & 47.7 \\
\hline DEA & 64.22 & 52.87 & $\begin{array}{l}33.16 \\
\times 1.9=62.89\end{array}$ \\
\hline DEA & 62.4 & 65.4 & $\begin{array}{l}31.1 \\
\times 1.9=61.88\end{array}$ \\
\hline DEA & 62.8 & 71.3 & $\begin{array}{l}34 \\
\times 1.9=64.6\end{array}$ \\
\hline TEA & 34.18 & 20.36 & 12.67 \\
\hline
\end{tabular}

Table 3 - Structures of alkanolamine absorbents used for present studies

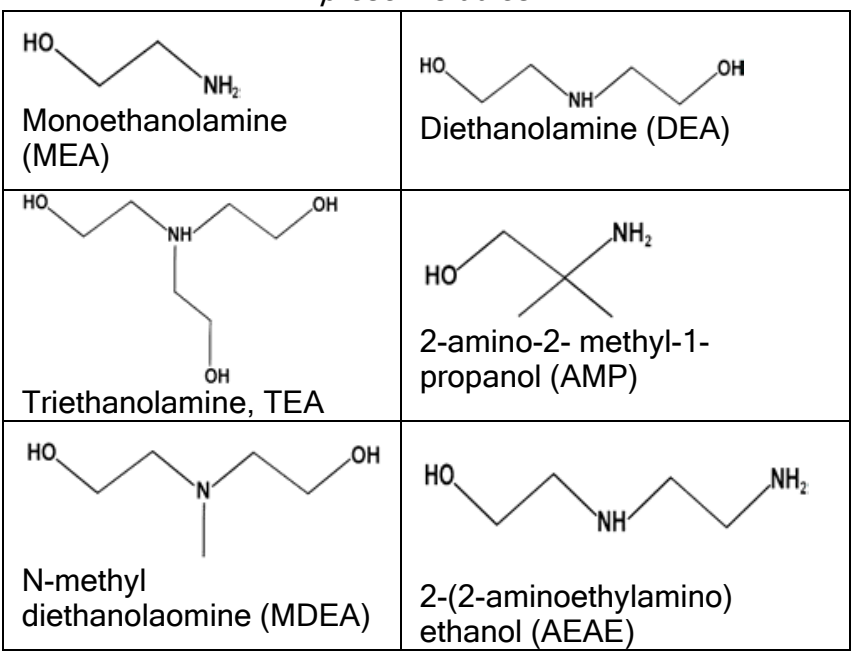
could be used for estimation of acidic component like $\mathrm{CO}_{2}$ in amine. corresponding values of aqueous solutions.

B. Basic principle behind the method developed: Alkanolamine being the basic molecule reacts with acidic components like $\mathrm{H}_{2} \mathrm{SO}_{4}$ or $\mathrm{CO}_{2}$ stoicheometrically (equations 1-6). When an acid is added to a known amount of amine the resulting $\mathrm{pH}$ is the measure of moles acid mole ${ }^{-1}$ amine reacted and indirectly the moles of amine left un-reacted. The stoicheometry is obtained after complete neutralization of amine with the acid by plotting $\mathrm{pH}$ against moles acid mole ${ }^{-1}$ amine added.

The stoicheometry of alkanol monoamines for sulphuric acid is 0.5 suggesting that two moles of amine are reacting with one mole of $\mathrm{H}_{2} \mathrm{SO}_{4}$ (Fig. 1, 2). In case of neutralization with weak monobasic organic acid, like acetic acid, a stoicheometry of nearly 0.31 was obtained from graph while for dibasic organic acid like oxalic acid the stoicheometry is nearly double as compared to that of monobasic organic acid i.e. $>0.6$. It was finalized that $\mathrm{H}_{2} \mathrm{SO}_{4}$ being strong acid dissociated completely. Research article CIndian Society for Education and Environment (iSee)
"pH-based $\mathrm{CO}_{2}$ estimation" http://www.indjst.org
C. Validation: Based on the above reasoning the validation was done for the results obtained for adding known volumes of saturated solution of $\mathrm{CO}_{2}$ containing known amount of $\mathrm{CO}_{2}$. Repeat values of 0.025 moles $\mathrm{CO}_{2} \mathrm{~L}^{-1}$ were obtained for $\mathrm{CO}_{2}$-saturated water as determined by alkaline $\mathrm{BaCl}_{2}$ precipitation. Same volumes $(5 \mathrm{~mL})$ of this $\mathrm{CO}_{2}$-saturated water, with known $\mathrm{CO}_{2}$ content, were added to each of the MEA, DEA and TEA samples simultaneously so that there was no time gap for escape of $\mathrm{CO}_{2}$ from water. Estimation of this $\mathrm{CO}_{2}$ in each amine was done by all the three $\left(\mathrm{MeONa}, \mathrm{BaCl}_{2}\right.$ and the present $\mathrm{pH}$ ) methods. As seen in Table 1 values of $\mathrm{CO}_{2}$ estimated in amine by the $\mathrm{pH}$ graph method are of very high accuracy as it matches with the alkaline $\mathrm{BaCl}_{2}$ results in water (error of only $4.4,0.88$ and $-5.5 \%$ for MEA, DEA and TEA respectively for such low amount as $5.6 \mathrm{mg}$ $\mathrm{CO}_{2}$ ). For secondary amine like DEA it was observed that the values obtained from $\mathrm{pH}$ graph needed to be multiplied by a factor of 1.9 for correct results. In case of $\mathrm{BaCl}_{2}$ method the error range was $17.5 ; 9.4$ and $37.7 \%$ and in case of MeONa method the error was -16.5, 45.8 and $66.7 \%$. These values of errors are rather high for dependable use.

It was also finalized that the reference $\mathrm{pH}$ graph of alkanolamine with $\mathrm{H}_{2} \mathrm{SO}_{4}$ gave most accurate results as compared to the $\mathrm{pH}$ graphs with organic acids.

D. Application of method to amines loaded with $\mathrm{CO}_{2}$ after absorption: Tabulated results of the amount of $\mathrm{CO}_{2}$ estimated in loaded alkanolamines after $\mathrm{CO}_{2}$ absorption (Table 2; Fig. 6) show a lot of variation in the repeat experiments for primary and secondary alkanolamines (MEA and DEA) by $\mathrm{MeONa}$ and $\mathrm{BaCl} 2$ methods. Results by the present $\mathrm{pH}$ method show good repeatability and high accuracy. Also the trend observed in case of the present method shows that capacity for absorption for secondary amine DEA is higher than primary amine Asha Masohan et al. Indian J.Sci.Technol. 
which is the observed trend for $\mathrm{CO}_{2}$ absorption. TEA shows lot of variation in $\mathrm{CO}_{2}$ content by the three methods. These results can throw an insight into the experimental results of absorption/desorption with different solvents when applied to the simulation modeling of the data by eNRTL where the predictions based on liquid analysis are still lacking because of dependable experimental data.

It is envisaged that the developed method can also be extended to mixtures of alkanolamines. Use of such mixtures is the latest state of the art in $\mathrm{CO}_{2}$ capture. Estimation of absorbed $\mathrm{CO}_{2}$ in the mixture will again require construction of the "reference $\mathrm{pH}$-graph" by plotting $\mathrm{pH}$ vs. moles of acid mole $\mathrm{e}^{-1}$ amine mixture as under 3 followed by validation and then estimating the $\mathrm{CO}_{2}$ content (4.2 and 4.3) in the mixture.

Conclusion

A novel, versatile and facile method has been developed for estimation of $\mathrm{CO}_{2}$ loaded into the alkanolamine with very good accuracy for use in data analysis. A pH graph of the methanolic solution of specific concentration of the amine (that is to be tested for $\mathrm{CO}_{2}$ absorption) with sulphuric acid is plotted as reference $\mathrm{pH}$ graph. The $\mathrm{CO}_{2}$ content is then obtained by noting $\mathrm{pH}$ of the $\mathrm{CO}_{2}$-loaded amine and referring to the $\mathrm{pH}$ graph for moles of $\mathrm{CO}_{2}$ mole $^{-1}$ amine and subsequently the weight of $\mathrm{CO}_{2}$ absorbed can be calculated using the molecular weight of amine. This method has the potential of application to other alkanolamines and to mixtures of alkanolamines as well. The method is applicable to full range of $\mathrm{CO}_{2}$ loading (from very low to high) in the solvent.

\section{Acknowledgement}

The authors thank Dr. S. Chandra, Jt. Advisor, Ministry of Chemicals and Fertilizers, New Delhi, India, for his constant encouragement and the Ministry of Chemicals and Fertilizer, Govt. of India, for financial assistance to carry out this study.

\section{References}

1. Arnold JL and Pearce RL (1960) Analysis of glycol and amine solutions and the interpretation thereof. Gas conditioning Inst., Liberal, Kansas.

2. Brydia LE and Pearce RL (1967) Quantitative gas chromatographic determination of ethanolamines as triflouroacetyl derivatives. Anal. Chem. 39, 1318-1320.

3. Coldrey PW and Harris IJ (1976) Kinetics of liquid phase reaction between carbon dioxide and Diethanolamine. Can. J. Chem. Eng. 54, 566-571.

4. Desideri U and Paolucci A (1999) Performance modeling of a carbon dioxide removal system for power plants. Energy Convrs. Manag. 40, 1899-1915.

5. Ellis GC, Leachman GS, Formaini RE, Hazelton RF and Smith WS (1963) Rate of desorption of carbon dioxide from Monoethanolamine solution, Proc. $13^{\text {th }}$ Ann. Gas Conditioning Conf. Univ. Oklahoma, p: B3.

6. Gas Conditioning Fact Book (1962) Dow Chemical Company, Midland, Michigan (c.f. - Ref.-4).

Research article

CIndian Society for Education and Environment (iSee)

"pH-based $\mathrm{CO}_{2}$ estimation" http://www.indjst.org
Table 4 - Experimental and literature values of $p K_{a} s$ of the alkanolamines and acids

\begin{tabular}{|c|c|c|c|}
\hline \multicolumn{4}{|l|}{ Amines } \\
\hline $\begin{array}{l}\text { Amine - acid } \\
\text { system }\end{array}$ & $\begin{array}{l}\mathrm{pK}_{\mathrm{a}} \text { in } \\
\text { methanolic } \\
\text { solution } \\
\text { (Exp.) }\end{array}$ & $\begin{array}{l}\mathrm{pK}_{\mathrm{a}} \text { in } \\
\text { aqueous } \\
\text { solution } \\
\text { (Perrin et } \\
\text { al.,1965) }\end{array}$ & $\begin{array}{l}\text { Range of } \\
\text { moles of acid } \\
\text { used mole }{ }^{-1} \\
\text { amine (max.) }\end{array}$ \\
\hline $\mathrm{MEA}-\mathrm{H}_{2} \mathrm{SO}_{4}$ & 9.4 & 9.51 & 0.50 \\
\hline MEA - Oxalic acid & 9.29 & & 0.60 \\
\hline DEA - Oxalic acid & 8.78 & & 0.60 \\
\hline DEA - $\mathrm{H}_{2} \mathrm{SO}_{4}$ & 8.72 & 8.95 & 0.5 \\
\hline $\mathrm{DEA}-\mathrm{HCl}$ & 8.66 & & 0.5 \\
\hline TEA - Oxalic acid & 7.71 & & 0.60 \\
\hline $\mathrm{TEA}-\mathrm{H}_{2} \mathrm{SO}_{4}$ & 7.5 & 7.78 & \\
\hline \multicolumn{4}{|l|}{ Acids } \\
\hline \multicolumn{4}{|c|}{ Literature value of $\mathrm{pK}_{\mathrm{a}}$} \\
\hline & pKa1 & \multicolumn{2}{|c|}{ pKa2 } \\
\hline $\begin{array}{l}\text { Acetic Acid } \\
\left(\mathrm{CH}_{3} \mathrm{COOH}\right)\end{array}$ & 4.74 & & \\
\hline $\begin{array}{l}\text { Carbonic Acid } \\
\left(\mathrm{H}_{2} \mathrm{CO}_{3}\right)\end{array}$ & 6.37 & \multicolumn{2}{|c|}{10.25} \\
\hline $\begin{array}{l}\text { Oxalic Acid } \\
{\left[(\mathrm{COOH})_{2}\right]}\end{array}$ & 1.23 & \multicolumn{2}{|c|}{4.19} \\
\hline $\begin{array}{l}\text { Sulfuric Acid } \\
\left(\mathrm{H}_{2} \mathrm{SO}_{4}\right)\end{array}$ & none & \multicolumn{2}{|c|}{1.92} \\
\hline
\end{tabular}

7. Hikita $\mathrm{H}$, Asai S, Ishikawa $\mathrm{H}$ and Honda M (1977) The kinetics of reactions of carbon dioxide with monoethanolamine, diethanolamine and triethanolamine by a rapid mixing method. Chem. Eng. J. 13, 7-12.

8. Jensen MB, Jorgensen $E$ and Faurholt C (1954) Reactions between carbon dioxide and amino alcohols. Acta Chem. Scand. 8, 1137-1140.

9. Jou FY, Mather AE and Otto FD (1982) Solubility of solution and carbon dioxide in aqueous Methyldiethanolamine solution. Ind. Eng. Chem. Process Des. Dev. 21, 539-544.

10. Perrin RG (1965, Supplement 1972) Dissociation constants of organic bases in aqueous solutions, Butterworths: London,

11. Robbins GD and Bullin JA (1984) Analysis of amine solutions by Gas Chromatography. Energy Progress. 4, 229-232.

12. UOP Method 826-81 (1981) Carbon dioxide in amine solution. ASTM Intl. Publ..

13. UOP Method 829-82. (1982) Titrimetric determination of $\mathrm{CO}_{2}$ in ethanolamines. ASTM Intl. Publ.

14. Weiland RH and Trass $O$ (1969) Titrimetric determination of acid gases in alkali hydroxides and amine, Anal. Chem. 41, 1709-1710.

15. White CM, Strazisar BR, Granite EJ, Hoffman JS and Pennline HW (2003) Separation and capture of $\mathrm{CO}_{2}$ from large stationary sources and sequestration in geological formation-coalbeds and deep saline aquifers, J. Air Waste Mangt. Assn. 53, 645-715. 